\title{
Status Kesehatan dan Uji Spesies Indikator Biologi Ekosistem Mangrove Teluk Yotefa Jayapura
}

\author{
John Dominggus Kalor ${ }^{1}$, Lisiard Dimara ${ }^{1}$, Ottouw G. Swabra', Kalvin Paiki ${ }^{2}$ \\ ${ }^{1}$ Program Studi Ilmu Kelautan, ${ }^{2}$ Program Studi IImu Perikanan, \\ Universitas Cenderawasih Jayapura \\ Email john_pela@yahoo.com
}

\begin{abstract}
This research was conducted to test the mangrove crab of Sesarmidae family as bio-indicator to assess health status of mangrove ecosystem in Youtefa Bay of Jayapura. Conducted since March-August 2017. Conducted in 3 stations namely St. Enggros, St.Tobati, and St. Nafri. Using the quadratic transect method $(1 \times 1 \mathrm{~m})$ and the quadratic transect $(10 \times 10 \mathrm{~m})$. Data were analyzed using index of diversity, dominance, evenness, abundance, density, simple linear regression and test criteria of indicator species. The result of the research found the level of mangrove diversity in Enggros Station with the value of index 1.9 then Tobati and Nafri Station of 1, 4 with abundant diversity level. The density of mangroves in the three stations is obtained by Enggors: 1455.6 trees / Ha, Naftri: 1477.8 trees / Ha, and Tobati 1033,5 trees / ha with moderate density categories and good ecosystem health conditions. The biological criteria indicator test shows that the Sesarmidae crab meets the six criteria of the indicator species, so that it can be designated as a species indicator of the health status of the ecosystem.
\end{abstract}

Keywords: Indicator, Crab, Sesarmidae, Mangrove, Youtefa, Jayapura.

\begin{abstract}
Abstrak
Penelitian ini dilakukan untuk menguji kepiting mangrove famili Sesarmidae sebagai bio-indikator untuk menilai status kesehatan ekosistem mangrove di Teluk Youtefa Jayapura. Dilakukan sejak bulan Maret sampai dengan Agustus 2017. Dilakukan di 3 stasiun yakni di St. Enggros, St.Tobati, dan St. Nafri dengan metode transek kuadrat $(1 \times 1 \mathrm{~m})$ dan transek kuadrat $(10 \times 10 \mathrm{~m})$. Data dianalisis menggunakan indeks keanekaragaman, dominansi, kemerataan, kelimpahan, kerapatan, regresi linear sederhana dan uji kritaria spesies indikator. Hasil penelitian menemukan tingkat keanekaragaman mangrove di Stasiun Enggros dengan nilai indeks 1,9 serta Stasiun Tobati dan Nafri sebesar 1, 4 dengan tingkat keanekaragaman sedang melimpah. Kerapatan mangrove pada ketiga stasiun diperoleh Enggors: 1455.6 pohon/Ha, Naftri: 1477.8 pohon/Ha, dan Tobati 1033,5 pohon/ha dengan katagori kerapatan sedang dan kondisi kesehatan ekosistem baik. Uji kriteria biologi indikator menunjukan kepiting Sesarmidae memenuhi enam kriteria spesies indikator, sehingga dapat ditetapkan sebagai spesies indikator status kesehatan ekosistem
\end{abstract}

Kata Kunci: Indikator, Kepiting, Sesarmidae, Mangrove, Youtefa, Jayapura

\section{Pendahuluan}

Kepiting mangrove hidup dan tersebar luas di seluruh tipe ekosistem mangrove, mulai dari ekosistem mangrove sepanjang pantai, sungai, delta, basin, dan juga ekosistem mangrove estuari. Kepiting mangrove berperanan dan befungsi penting secara ekologi untuk keberlanjutan ekosistem mangrove (Kathiresan \& Bingham, 2001; Ashton et al., 2003). Sebab itu kepiting mangrove disebut sebagai "the ecosystem engineer and the keystone species of mangrove ecosystem" (Nordhaus, 2003). Kepiting mangrove juga memiliki nilai potensi ekonomi dan budaya, misalnya, Scylla serrata, $S$. paramamosain, $S$. transquebarica dan $S$. olivacea,S. oceanica, (Macintosh \& Ashton, 2002; Geisen et al., 2007).

Ashton et al. (2002), menjelaskan bahwa keanekaragaman dan struktur komonitas kepiting memiliki korelasi yang nyata dengan vegetasi mangrove di Serawak, Malaysia. Kalor (2012) menyebutkan komonitas mangrove dan populasi kepiting (keanekaragaman dan kepadatan) memiliki hubungan ekologi yang signifikan, dan sangat dipengaruhi oleh kehadiran dua famili Ocypodidae dan Sesarmidae. Kedua famili kepiting ini dapat digunakan sebagai indikator biologi, namun diperlukan informasi yang lengkap tentang kontribusi spesies tersebut dalam ekosistem, serta posisinya dalam taraf tropik.

Kalor (2012) menegaskan bahwa kepiting mangrove dapat digunakan sebagai biologi indikator, sebab spesies tersebut dapat merefleksikan kondisi ekosistem mangrove yang sebenarnya. Kalor (2012) menjelaskan pula bahwa penelusuran spesies indikator harus memperhatikan level gangguan ekosistem mangrove, yang dapat dikatagorikan menjadi level gangguan rendah, level sedang, dan tinggi. Sudah tentu tingkat kehadiran dan populasi kepiting mangrove pada setiap kondisi ekosistem berbeda, tergantung dan ditentukan oleh kemampuan adaptasi spesies kepiting tersebut.

Dalam kaitan tersebut perlu dilakukan suatu penelitian yang mendalam tentang spesies indikator ekosistem mangrove, berdasarkan penelitian sebelumnya yang mengarahkan pada 
penggunaan dan pemanfaatan famili Sesarmidae sebagai kandidat indikator kesehatan ekosistem mangrove. Lokasi penelitian diprioritaskan pada ekosistem yang memiliki level gangguan sedang dan tinggi, seperti ekosistem mangrove di teluk Yotefa Jayapura. Kawasan teluk Yotefa berbatasan langsung dengan pemukiman penduduk, sehingga level gangguannya diprediksikan tinggi.

Indikator biologi merupakan alat pengelolaan yang berperan penting dalam menentukan kualitas ekosistem (lingkungan). Banyak spesies/kelompok biota darat/air yang telah digunakan sebagai indikator kualitas ekosistem (lingkungan), namun pemanfaatannya bersifat ujicoba dan tidak dilandasi pengujian secara empiris. Hal ini menyebabkan "parameter uji" yang dimilikinya oleh setiap spesies menjadi rendah dan tidak dapat dipergunakan sebagai suatu alat dalam pengelolaan lingkungan. Penelitian ini bertujuan untuk menguji dan menganalisis spesies i ndikator kepiting mangrove famili sesarmidae sebagai bio-indikator kesehatan ekosistem mangrove Teluk Yotefa.

\section{Metode Penelitian}

\section{Lokasi Penelitian}

Penelitian ini dilakukan di kawasan hutan mangrove teluk Yotefa, Jayapura. Pengambilan data dilakukan sejak bulan Maret sampai dengan Agustus 2017. Lokasi penelitian dibagi menjadi tiga stasiun penelitian, yang tersebar di Pesisir Nafri, Pesisir Enggros, dan Pesisir Tobati. Kawasan ini berbatasan secara langsung dengan populasi manusia, terindikasi memiliki level gangguan yang tinggi.

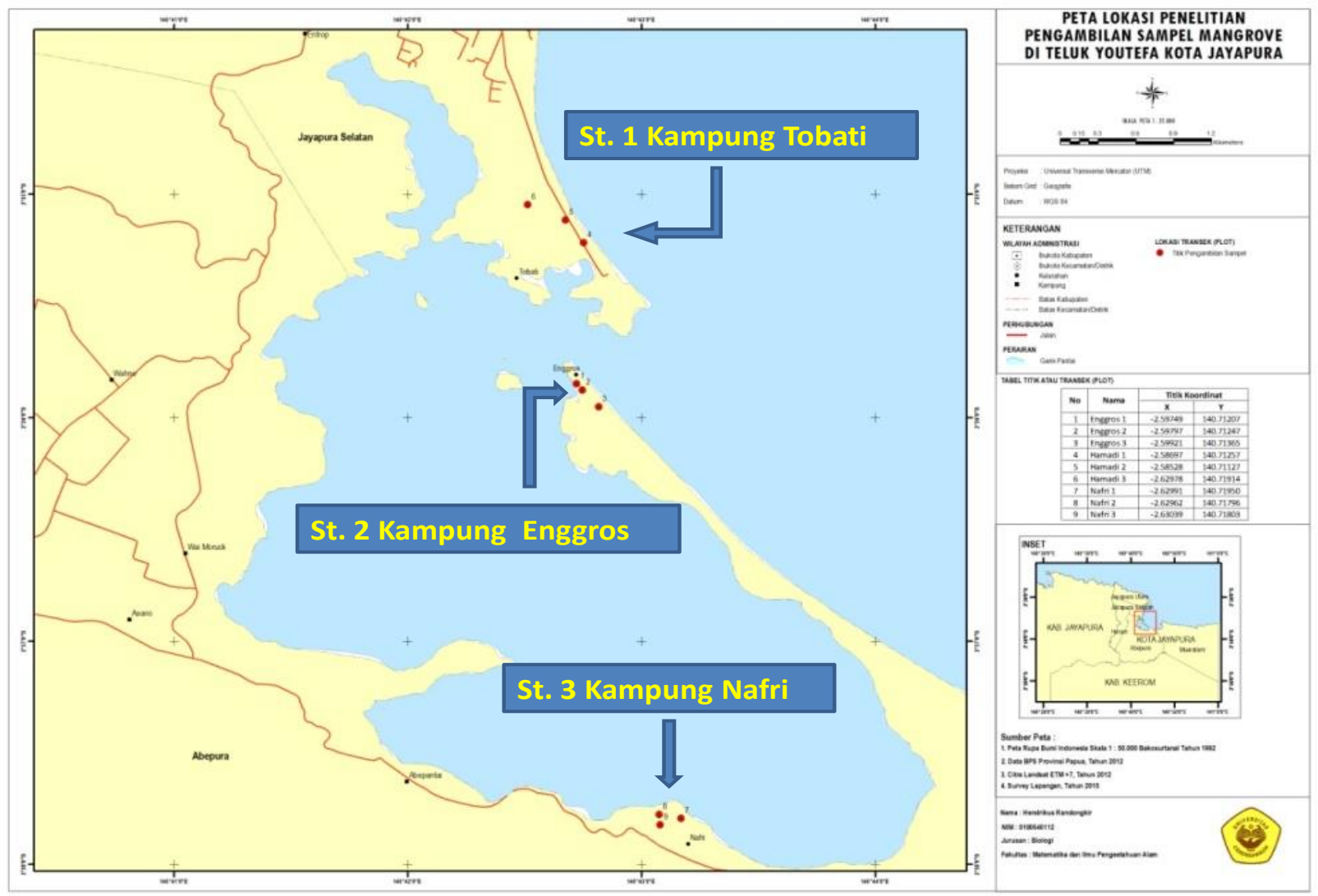

Gambar 1. Lokasi Penelitian Ekosistem Mangrove Teluk Youtefa

\section{Metode Pengambilan Data}

1. Transek kuadrat digunakan untuk pengambilan sampel kepiting mangrove. Panjang transek 50 meter, terdapat 9 kuadrat dengan ukuran $1 \mathrm{~m} x$ $1 \mathrm{~m}$ dalam setiap transek. Untuk mendapatkan data tipe habitat dan ekosistem, maka dibuat 3 stasiun penelitian, setiap stasiun memiliki 3 transek.

2. Transek kuadrat untuk pengambilan sampel mangrove. Panjang transek 50 meter, terdapat
3 kuadrat dengan ukuran $10 \mathrm{~m} \times 10 \mathrm{~m}$ dalam setiap transek. Ada 3 stasiun dam terdapat 3 transek untuk setiap stasiun. Untuk pengambilan data mangrove tingkat tiang dan pohon dengan diameter $10-20 \mathrm{~cm}$. Untuk mendapatkan data tipe habitat dan ekosistem, maka dibuat 3 stasiun penelitian, setiap stasiun memiliki 3 transek. 


\section{Analisis Data}

1. Analisis tingkat Keanekaragaman Spesies menggunakan Indeks Shannon-Wiener $\left(\mathrm{H}^{\prime}\right)$ $H^{\prime}=-\sum p i \ln 2 p i \quad$ (Magurran, 1988; Krebs, 1985; Jorgensen et al., 2005). Dimana pi= $\mathrm{ni} / \mathrm{N}, \mathrm{N}=$ jumlah total individu, $\mathrm{ni}=$ jumlah individu jenis ke-i. Menurut Fachrul (2007) nilai $\mathrm{H}>3$ menunjukan keanekaragaman spesies melimpah, $\leq 1 \mathrm{H} \leq 3$ keanekaragaman spesies sedang melimpah, dan nilai $H<1$ keanekaragaman spesies rendah

2. Analisis Dominansi menggunakan Indeks Simpson $\quad D=\sum_{i=1}^{S}\left[\frac{n i}{N}\right]^{2} \quad$ (Magurran, 1988; Krebs, 1985; Jorgensen et al., 2005). Bila $D \approx 0$ berarti tidak ada spesies yang mendominansi dan $D=1$ berarti terdapat spesies yang mendominansi

3. Analisisi Kemerataan (Khouw, 2009) menggunakan $E=\frac{H^{i}}{\ln (S)}$ Dimana: $\mathrm{E}=$ Indeks kemerataan jenis, $H^{\prime}=$ Indeks keanekaragaman jenis, $\mathrm{S}=$ Jumlah jenis. Jika besaran $E^{\prime}<0.5$ kemerataan jenis tergolong rendah (komunitas dalam kondisi tertekan), E' $=0.5-0.75$ kemerataan sedang (komunitas labil) dan $E^{\prime}>0.75$ kemerataaan tinggi (komunitas stabil).

4. Analisis Kelimpahan Caughley (Khouw, 2009), Kepadatan setiap unit sampling (kuadran) dengan $\bar{D}=\frac{x}{z}$, menghitung kepadatan ratarata dengan $\bar{D}=\frac{\sum D}{n}$, menghitung besar populasi dengan $B=\bar{D} Z$, dimana $D=$ Kepadatan suatu unit sampling ke-i, $x=$ jumlah organisme pada unit sampling ke-l, $z$ = luas unit sampling, $n=$ jumlah unit sampling, $Z=$ total luas area sampling, $\bar{D}=$ rata-rata kepadatan per luas unit sampling.

5. Analaisis Kerapatan (K), menurut Fachrul, (2007) kerapatan mangrove dapat dihitung dengan rumus: Kerapatan $(K)=\frac{\text { jumlah total individu suatu jenis }}{\text { luas total area }}$ Nilai kerapatan mangrove hasil perhitungan akan diuji dengan kriteria tingkat kerusakan ekosistem mangrove menurut Kepmen Lingkungan Hidup, Nomor 21 tahun 2004 (Tabel 1)

Tabel 1. Kriteria Tingkat Kerusakan Mangrove

\begin{tabular}{llll}
\hline \multicolumn{2}{c}{ Kriteria } & $\begin{array}{c}\text { Penutupan } \\
(\%)\end{array}$ & $\begin{array}{l}\text { Kerapatan } \\
\text { (Pohon/ha) }\end{array}$ \\
\hline Baik & Sangat & $\geq 75$ & $\geq 1500$ \\
& Padat & & $\geq 1000-$ \\
Baik & Sedang & $\geq 50-<75$ & $<1500$ \\
Rusak & Jarang & $<50$ & $<1000$ \\
\hline
\end{tabular}

Sumber : Kepmen Lingkungan Hidup, Nomor 21 tahun 2004

6. Analisis ini menggunakan model regresi linier sederhana yaitu $Y=a+b x$ dimana $Y=$ Kelimpahan Kepiting Sesarmidae, $\mathrm{x}=$ Kerapatan Mangrove, $a=$ intersep $b=$ Slope. Untuk menganalsis hubungan kerapatan mangrove dengan kelimpahan kepiting Sesamidae

7. Identifikasi tumbuhan mangrove menggunakan Noor at al. (1999) dan indentifikasi kepiting mangrove menggunakan Rahayu dan Setyadi (2009)

8. Uji Kriteria Spesies Indikator. Kepiting Sesarmidae diuji menggunakan 6 kriteria spesies biologi indikator yang tercantum dalam tabel 2.

Tabel 2. Kriteria yang digunakan dalam Uji spesies indikator Kepiting Mangrove

\begin{tabular}{|c|c|c|}
\hline No & Kriteria & Uji Kreteria menggunakan \\
\hline 1 & $\begin{array}{l}\text { Memiliki taksonomi, biologi, dan ekologi yang } \\
\text { jelas dan diketahui dengan baik }\end{array}$ & $\begin{array}{l}\text { Analisis diskriptif kualitatif dengan buku } \\
\text { identifikasi }\end{array}$ \\
\hline 2 & $\begin{array}{l}\text { Korelasi terhadap perubahan ekosistem dapat } \\
\text { ditetapkan }\end{array}$ & $\begin{array}{l}\text { Analisis indeks keanekaragaman, indeks } \\
\text { kemerataan }\end{array}$ \\
\hline 3 & Sensitif terhadap tekanan lingkungan & $\begin{array}{l}\text { Analisis kelimpahan dan simple linear } \\
\text { regresi }\end{array}$ \\
\hline 4 & Spesialisasi & Analisis Dominansi \\
\hline 5 & Penghuni tetap dan asli setempat & Analisis perilaku \\
\hline 6 & $\begin{array}{l}\text { Memiliki kebutuhan habitat yang sama dengan } \\
\text { organisme lain dan habitatnya lebih heterogen }\end{array}$ & Analisis diskriptif kualitatif \\
\hline
\end{tabular}

\section{Hasil dan Pembahasan}

\section{Status Ekosistem Mangrove menurut Parameter Fisik dan Kimia Lingkungan}

Hasil pengukuran salinitas di ketiga stasiun cukup tinggi yaitu 41-45 ppt dan hasil ini sesuai, sebab tidak ditemukan adanya aliran air tawar dalam jumlah besar masuk ke ekosistem mangrove, sehingga salinitas relative tinggi (table 3). Menurut Kathirvel at al., (1999), kepiting mangrove hidup pada perairan yang memiliki kisaran salinitas antara 0-45 ppt. Suhu perairan pada setiap stasiun berkisar antara $29-30^{\circ} \mathrm{C}$ (tabel 3), dan dikategorikan dalam kondisi suhu yang 
dapat ditoleransi oleh kepiting mangrove. Cholik (2005), menyatakan suhu yang sesuai untuk kepiting mangrove adalah $18-35^{\circ} \mathrm{C}$ dan suhu yang ideal adalah $25-30^{\circ} \mathrm{C}$. Supriharyono (2000) mengatakan suhu yang cocok untuk pertumbuhan mangrove tidak kurang dari $20-40^{\circ} \mathrm{C}$.

Kadar derajat keasaman $(\mathrm{pH})$ diperoleh dari hasil pengukuran pada ketiga stasiun pengamatan yaitu 6,5-6,8 (tabel 3), nilai tersebut sesuai untuk kehidupan kepiting mangrove. Wahyuni dan Ismail (1987), menjelaskan kepiting mangrove dapat hidup pada kondisi perairan asam yaitu daerah yang bersubstrat lumpur dengan $\mathrm{pH}$ rata-rata 6,5. Menurut Yudistra (2011) $\mathrm{pH}$ perairan yang baik berkisar antara $6.5-8.20$ sesuai untuk kelangsungan hidup mangrove dan biota-biota intertidal yang berasosiasi didalamnya.

Menurut Kordi (2000), kepiting dapat hidup pada perairan yang memiliki kandungan oksigen terlarut lebih dari $4 \mathrm{mg} / \mathrm{liter}$, menurut Kementerian Lingkungan Hidup (2004) yaitu berkisar antara $5.00 \mathrm{mg} / \mathrm{L}-8.05 \mathrm{mg} / \mathrm{L}$. Hasil pengukuran menunjukan kandungan oksigen terlarut yang terdapat pada ketiga lokasi sudah sesuai untuk kepiting mangrove (tabel 3 ).

Tabel 3 Parameter Fisika dan Kimia Lingkungan di Kampung Tobati, Enggros, dan Nafri

\begin{tabular}{llccccccccc}
\hline \multirow{2}{*}{ No } & \multirow{2}{*}{ Parameter } & \multicolumn{3}{c}{ Stasiun Tobati } & \multicolumn{3}{c}{ Stasiun Enggros } & \multicolumn{3}{c}{ Stasiun Nafri } \\
\cline { 3 - 11 } & & T 1 & T 2 & T 3 & T 4 & T 5 & T 6 & T 7 & T 8 & T 9 \\
\hline 1 & Salinitas & 44 & 45 & 45 & 41 & 45 & 42 & 45 & 41 & 42 \\
2 & Suhu & 29 & 26 & 30 & 29.9 & 30 & 31 & 29 & 32.5 & 33.2 \\
3 & pH & 6,07 & 6.70 & 6.75 & 6,5 & 6,7 & 6.25 & 6.65 & 6.18 & 6.8 \\
4 & DO & 4.39 & 4.40 & 5.45 & 4.07 & 4.23 & 5.86 & 5.30 & 4.35 & 4.40 \\
5 & Substrat & LB & LB & B & PB & L & L & B & B & B \\
\hline
\end{tabular}

Keterangan: $B=$ Belumpur; $L=$ Lumpur; $P B=$ Pasir berlumpur, $L B=$ Lumpur berpasir

\section{Status Ekosistem Menurut Tingkat Keanekaragaman dan Kerapatan Mangrove}

Ekosistem mangrove Teluk Youtefa menujukan karakter vegetasi yang heterogen seperti karakter hutan mangrove Papua pada umumnya (Wells 2007), namun pada lokasi tertentu karakter vegetasi menjadi homogen yang bersesuaian dengan zonasi spesies. Karakter tersebut teramati dan terekam dengan jelas melalui penelitian ini dengan mengidentifikasi 9 spesies dan 7 Famili mangrove, semua spesies tersebut tersebar di kawasan ekosistem mangrove Teluk Youtefa. Stasiun Enggros memiliki 7 spesies dan 5 famili mangrove, Nafri memiliki 6 spesies dan 4 famili mangrove, dan Tobati memiliki 5 spesies dan 3 famili mangrove (Tabel 4). Dari ketiga stasiun tersebut, Stasiun Enggros yang memiliki spesies dan famili lebih banyak jika dibandingkan dengan Nafri dan Tobati.

Tingkat keanekaragaman spesies mangrove di Stasiun Enggros dengan nilai indeks 1,9 serta Stasiun Tobati dan Nafri dengan nilai indeks 1,4 . Jika digabungkan data jumlah spesies dan individu untuk ketiga stasiun maka diperoleh nilai keanekaragamannya adalah 2,0. Menurut Fachrul (2007), jika nilai keanekaragaman $\leq 1 \mathrm{H}$ $\leq 3$ maka dikatagorikan tingkat keanekaragamannya sedang melimpah. Tingkat keanekargaman tumbuhan mangrove di teluk Youtefa sangat dipengaruhi oleh bentuk fisik teluk, letak geografis, eseanografi dan ekologi teluk Youtefa. Menurut Odum (1998) tingkat keanekaragaman spesies sangat berhubungan dengan kondisi ekosistem, dimana keanekaragaman tinggi maka ekosistemnya baik dan keanekaragaman rendah maka ekosistemnya rusak.

Kerapatan mangrove pada ketiga stasiun yang dihitung berdasarakan perbandingan luas area dan jumlah individu mangrove diperoleh Enggors: 1455.6 pohon/Ha, Naftri: 1477.8 pohon/Ha, dan Tobati 1033,5 pohon/ha atau kerapatan ketiga lokasi berada dalam kisaran $\geq$ 1000 - 1500 (bandingkan data pada table 4), berarti hutan mangrove berada dalam katagori kerapatan sedang dan baik. Tidak dapat dipungkiri bahwa itergritas ekosistem mangrove disini memang sangat memprihatinkan, karena ancaman framentasi lahan, konfersi hutan, dan pencemaran yang terjadi terus menerus di Teluk Youtefa.

Menurut Jorgensen et al., (2005), yang dimaksudkan dengan integritas ekosistem adalah kemampuan dari satu ekosistem untuk memelihara organisasi. Sementara Primack (2006) mendeskripsikan integritas ekosistem sebagai suatu kondisi dimana komponenkomponen ekosistem terpenuhi dengan baik dan fungsional. Menurut Jorgensen et al., (2005) organisasi ekosistem mencakup dua aspek yaitu fungsi dan struktur dari ekosistem, fungsi merujuk pada keseluruhan aktivitas yang terdapat dalam ekosistem dan struktur merujuk pada interkoneksi antara komponen-komponen dari ekosistem tersebut. 
Tabel 4. Data Keanekaragaman dan Kerapatan Mangrove di Stasiun Tobati, St. Enggros, dan St. Nafri

\begin{tabular}{|c|c|c|c|c|c|c|c|c|c|c|}
\hline \multirow{2}{*}{ Famili } & \multirow{2}{*}{ Spesies } & \multicolumn{3}{|c|}{ Enggros } & \multicolumn{3}{|c|}{ Nafri } & \multicolumn{3}{|c|}{ Tobati } \\
\hline & & $\mathbf{N}$ & $\mathrm{H}$ & $\mathrm{K}$ & $\mathbf{N}$ & $\mathbf{H}$ & $\mathbf{K}$ & $\mathbf{N}$ & $\mathbf{H}$ & $\mathrm{K}$ \\
\hline Avicennia & $A a$ & 0 & 0.0 & 0.0 & 33 & 0.0 & 366.7 & 0 & 0.0 & 0.0 \\
\hline Rhizophoraceae & $B c$ & 29 & 0.3 & 322.2 & 17 & 0.3 & 188.9 & 55 & 0.4 & 0.2 \\
\hline Rhizophoraceae & $B g$ & 23 & 0.3 & 255.6 & 19 & 0.3 & 211.1 & 46 & 0.4 & 511.1 \\
\hline Leguminosaceae & $D t$ & 8 & 0.2 & 88.9 & 24 & 0.3 & 266.7 & 9 & 0.2 & 100.0 \\
\hline Combretaceae & LI & 21 & 0.3 & 233.3 & 0 & 0.0 & 0.0 & 0 & 0.0 & 0.0 \\
\hline Rhizophoraceae & $R a$ & 23 & 0.3 & 255.6 & 19 & 0.3 & 211.1 & 10 & 0.2 & 111.1 \\
\hline Rhizophoraceae & $R m$ & 27 & 0.3 & 300.0 & 21 & 0.3 & 233.3 & 28 & 0.3 & 311.1 \\
\hline Sonneratiaceae & Sa & 0 & 0.0 & 0.0 & 0 & 0.0 & 0.0 & 0 & 0.0 & 0.0 \\
\hline Meliaceae & $X m$ & 8 & 0.2 & 88.9 & 0 & 0.0 & 0.0 & 0 & 0.0 & 0.0 \\
\hline 7 Famili & 9 spesies & 131 & 1.9 & 1455.6 & 133 & 1.4 & 1477.8 & 148 & 1.4 & 1033.5 \\
\hline
\end{tabular}

Keterangan: $\mathrm{Aa}=\overline{\text { Avicenia alba, } B c=\text { Bruguiera cylindrica, } B g=B r u g u i e r a}$ gymnosriza,Dt= Derris trifolia, $L I=L u m n i t z e r a$ littorea, $R a=$ Rhizophora apiculata, $R m=$ Rhizophora mucronata, Sa= Sonneratia alba, Xm=Xylocarpus molucensis

Untuk mengukur integritas ekosistem, maka dapat digunakan spesies indikator dan nilai diversity (Jorgensen et al., 2005). Menurut FaberLangendoen, et al., (2011), pengukuran integritas ekosistem dapat menggunakan suatu model pengujian intensif atau penilaian intensif, yang dimaksudkan dengan penilaian intensif adalah evaluasi kondisi individu penggunaan kejadian secara relatif bidang kwantitatif yang terperinci indikator. Penilaian dapat berlandaskan indikator yang telah dikalibrasi untuk mengukur tanggapan dari sistem ke berbagai gangguan.

\section{Status Populasi Kepiting Famili Sesarmidae dalam Ekosistem Mangrove Teluk Youtefa}

Kepiting famili Sesarmidae bukanlah satusatunya famili kepiting yang hidup di ekosistem mangrove. Menurut Kalor (2012) ada beberapa famili lain yang selalu dijumpai ekosistem mangrove diantaranya Ocypodoidea, Portunidae, Eriphioidea, dan Grapsoidea. Semua famili kepiting tersebut secara perilaku berbeda dengan Sesarmidae, meskipun kepiting-kepiting itu tersebut sama-sama hidup di ekosistem mangrove. Hanyalah kepiting famili Sesarmidae yang cukup menonjol dalam perilaku, spesies ini sering disebut dengan kepiting pemanjat karena perilaku kepiting yang selalu memanjat akar dan batang pohon mangrove serta berdiam disana.

Tabel 5. Populasi Kepiting Mangrove Famili Sesarmidae di Teluk Youtefa

\begin{tabular}{|c|c|c|c|c|c|c|c|c|c|c|c|c|c|}
\hline \multirow{2}{*}{ No } & \multirow{2}{*}{ Spesies } & \multicolumn{4}{|c|}{ Engros } & \multicolumn{4}{|c|}{ Nafri } & \multicolumn{4}{|c|}{ Tobati } \\
\hline & & $\mathrm{N}$ & $\mathrm{H}$ & D & $E$ & $\mathrm{~N}$ & $\mathrm{H}$ & D & $E$ & $\mathrm{~N}$ & $\mathrm{H}$ & $\mathrm{D}$ & $E$ \\
\hline 1 & Clistocoeloma sp & 0 & 0.00 & 0.0 & 0.0 & 0 & 0.00 & 0.00 & 0.00 & 9 & 0.36 & 0.10 & 0.23 \\
\hline 2 & Neosarmatium sp & 6 & 0.21 & 0.01 & 0.11 & 0 & 0.00 & 0.00 & 0.00 & 5 & 0.31 & 0.03 & 0.19 \\
\hline 3 & Parasesarma sp & 8 & 0.25 & 0.01 & 0.13 & 6 & 0.21 & 0.01 & 0.11 & 6 & 0.33 & 0.05 & 0.21 \\
\hline 4 & $\begin{array}{l}\text { Parasesarma } \\
\text { plicatum }\end{array}$ & 7 & 0.23 & 0.01 & 0.12 & 6 & 0.21 & 0.01 & 0.11 & 0 & 0.00 & 0.00 & 0.00 \\
\hline 5 & $\begin{array}{l}\text { Parasesarma } \\
\text { guttatum }\end{array}$ & 3 & 0.14 & 0.00 & 0.07 & 0 & 0.00 & 0.00 & 0.00 & 0 & 0.00 & 0.00 & 0.00 \\
\hline 6 & Perisesarma sp & 14 & 0.33 & 0.04 & 0.17 & 14 & 0.32 & 0.04 & 0.16 & 4 & 0.28 & 0.02 & 0.17 \\
\hline 7 & Perisesarma indiarum & 21 & 0.36 & 0.10 & 0.19 & 23 & 0.37 & 0.10 & 0.19 & 4 & 0.28 & 0.02 & 0.17 \\
\hline 8 & Perisesarma huzardi & 0 & 0.00 & 0.00 & 0.00 & 8 & 0.25 & 0.01 & 0.13 & 0 & 0.00 & 0.00 & 0.00 \\
\hline 9 & Perisesarma eumolpe & 0 & 0.00 & 0.00 & 0.00 & 7 & 0.23 & 0.01 & 0.12 & 0 & 0.00 & 0.00 & 0.00 \\
\hline 10 & Selatium elongatum & 9 & 0.27 & 0.02 & 0.14 & 7 & 0.23 & 0.01 & 0.12 & 0 & 0.00 & 0.00 & 0.00 \\
\hline 11 & Jumlah & 68 & 1.79 & 0.19 & 0.92 & 71 & 1.81 & 0.19 & 0.93 & 28 & 1.56 & 0.22 & 0.97 \\
\hline
\end{tabular}

Keterangan: $\mathrm{n}=$ jumlah individu, $\mathrm{H}=$ Indeks Diversitas, $\mathrm{D}=$ Dominasi, $\mathrm{E}=$ Kemerataan 
Perilaku Sesarmidae ini membentuk suatu ikatan khusus antara populasi kepiting terhadap vegetasi tumbuhan mangrove sebagai habitatnya. Populasi kepiting di teluk Youtefa yang diamati disini tersebar di Stasiun Enggros, Nafri, dan Tobati. Dimana dari 68 individu yang teramati terdapat 5 genus dan 10 spesies, dari semua speseis ada 2 yang dominan yaitu Perisesarma sp dan Perisesarma indiarum. Perhitungan indeks keanekaragaman menunjukan tingkat keanekaragaman spesies di Stasiun Enggros 1,79, Stasiun Nafri 1,81 dan Satsiun Tobati 1,6, ketiga stasiun memiliki keanekeragaman spesies sedang melimpah.

Data populasi kepiting Sesarmidae di Teluk Youtefa pada tabel 5, menunjukan nilai dominansi spesies menunjukan Stasiun Enggros 0,19,
Stasiun Nafri 0,19 dan Satsiun Tobati 0,22 dan hasil perhitungan ini mengidikasikan bahwa tidak ditemukan spesies bersifat dominan pada ketiga stasiun. Artinya tidak ada spesies yang menonjol menurut jumlah individu dan distribusi dalam populasi kepiting famili Sesarmidae di Teluk Youtefa. Indeks kemerataan spesies yang dihtung pada stasiun Enggros 0,92 stasiun Nafri 0,93 dan satsiun Tobati 0,97 , sehingga dapat diketahui ketiga lokasi ini memeliki komunitas yang seragam. Menurut Primack (2006), kondisi ini dapat dipengaruhi oleh hubungan antara suatu sub populasi dengan sub populasi lainnya yang menempati suatu area yang sama dan saling berinteraksi, serta membentuk suatu ikatan yang disebut meta populasi.

Tabel 6. Populasi Kepiting Mangrove Famili Sesarmidae di Teluk Youtefa

\begin{tabular}{clcccccc}
\hline \multirow{2}{*}{ No Spesies } & & \multicolumn{2}{c}{ Engros } & \multicolumn{2}{c}{ Nafri } & \multicolumn{2}{c}{ Tobati } \\
\cline { 3 - 8 } & & $\mathrm{N}$ & $\dot{\mathrm{D}}$ & $\mathrm{N}$ & $\dot{\mathrm{D}}$ & $\mathrm{N}$ & $\dot{\mathrm{D}}$ \\
\hline 1 & Clistocoeloma sp & 0 & 0.00 & 0 & 0.00 & 9 & 0.11 \\
2 & Neosarmatium sp & 6 & 0.07 & 0 & 0.00 & 5 & 0.06 \\
3 & Parasesarma sp & 8 & 0.10 & 6 & 0.07 & 6 & 0.07 \\
4 & Parasesarma plicatum & 7 & 0.09 & 6 & 0.07 & 0 & 0.00 \\
5 & Parasesarma guttatum & 3 & 0.04 & 0 & 0.00 & 0 & 0.00 \\
6 & Perisesarma sp & 14 & 0.17 & 14 & 0.17 & 4 & 0.05 \\
7 & Perisesarma indiarum & 21 & 0.26 & 23 & 0.28 & 4 & 0.05 \\
8 & Perisesarma huzardi & 0 & 0.00 & 8 & 0.10 & 0 & 0.00 \\
9 & Perisesarma eumolpe & 0 & 0.00 & 7 & 0.09 & 0 & 0.00 \\
10 & Selatium elongatum & 9 & 0.11 & 7 & 0.09 & 0 & 0.00 \\
& Jumlah & 68 & 0.84 & 71 & 0.88 & 28 & 0.35 \\
& Kepadatan unit Sampling & 0.84 & & 0.88 & & 0.35 & \\
& Kepadatan rata-rata & 0.09 & & 0.10 & & 0.04 & \\
& Besar Populasi Kepiting & 84 & & 88 & & 35 & \\
\hline Ketanyyyyyyyyyyyy
\end{tabular}

Keterangan: $\mathrm{n}=$ jumlah individu, $\dot{\mathrm{D}}=$ Kelimpahan

Nilai kelimpahan spesies menunjukan Stasiun Enggros 0,84, Stasiun Nafri 0,88 dan Satsiun Tobati 0,35 (Tabel 6). Hasil perhitungan ini menunjukan spesies tidak terlalu melimpah pada ketiga stasiun, dengan kisaran kepadatan rata-rata $0.04-0.09$ per unit sampling. Dengan demikian populasi yang ditemukan di ketiga lokasi adalah untuk Stasiun Enggros 84 individu, Stasiun Nafri 88 individu danStasiun Tobati 35 individu.

\section{Validasi Kreteria Bioindikator terhadap Kepiting Famili Sesarmidae}

Analisis linier regresi sederhana
menunjukan kelimpahan kepiting sangat
dipengaruhi dan ditentukan oleh kepadatan
mangrove, dengan koefisien deterninasi $\left(\mathrm{R}^{2}\right)=$
0,9994. Jika kepadatan dan luas area ekosistem mangrove bertambah maka kelimpahan kepiting juga bertambah, dan apabila luas area dan kepadatan ekosistem mangrove berkurang dengan nyata maka kelimpahan kepiting dengan sendirinya akan berkurang.

Validasi kriteria indikator biologi menunjukan kepiting Sesarmidae berhasil memenuhi ini enam kriteria yang ditetapkan sebagai spesies indikator (Tabel 7). Perubahan struktur populasi kepiting Sesarmidae mengindikasikan perubahan kualitas lingkungan dan adanya pencemaran serta penurunan kerapatan vegetasi ekosistem mangrove. Hasil penelitian ini juga menujukan kepiting Sesarmidae dapat digunakan sebagai alat indikator biologi untuk menentukan kualitas lingkungan ekosistem 
mangrove. Menggunakan indikator biologi untuk mengidentifikasi status kesehatan suatu eksosistem tidak semudah yang diperkirakan, kerena karaketeristik biologi dan ekologi setiap ekosistem berbeda. Untuk itu diperlukan seleksi spesies indikator yang tepat berdasarkan karekteristik ekosistem tersebut, level dari gangguan dan ancaman terhadap ekosistem, dan kreteria spesies bioindikator yang akurat.

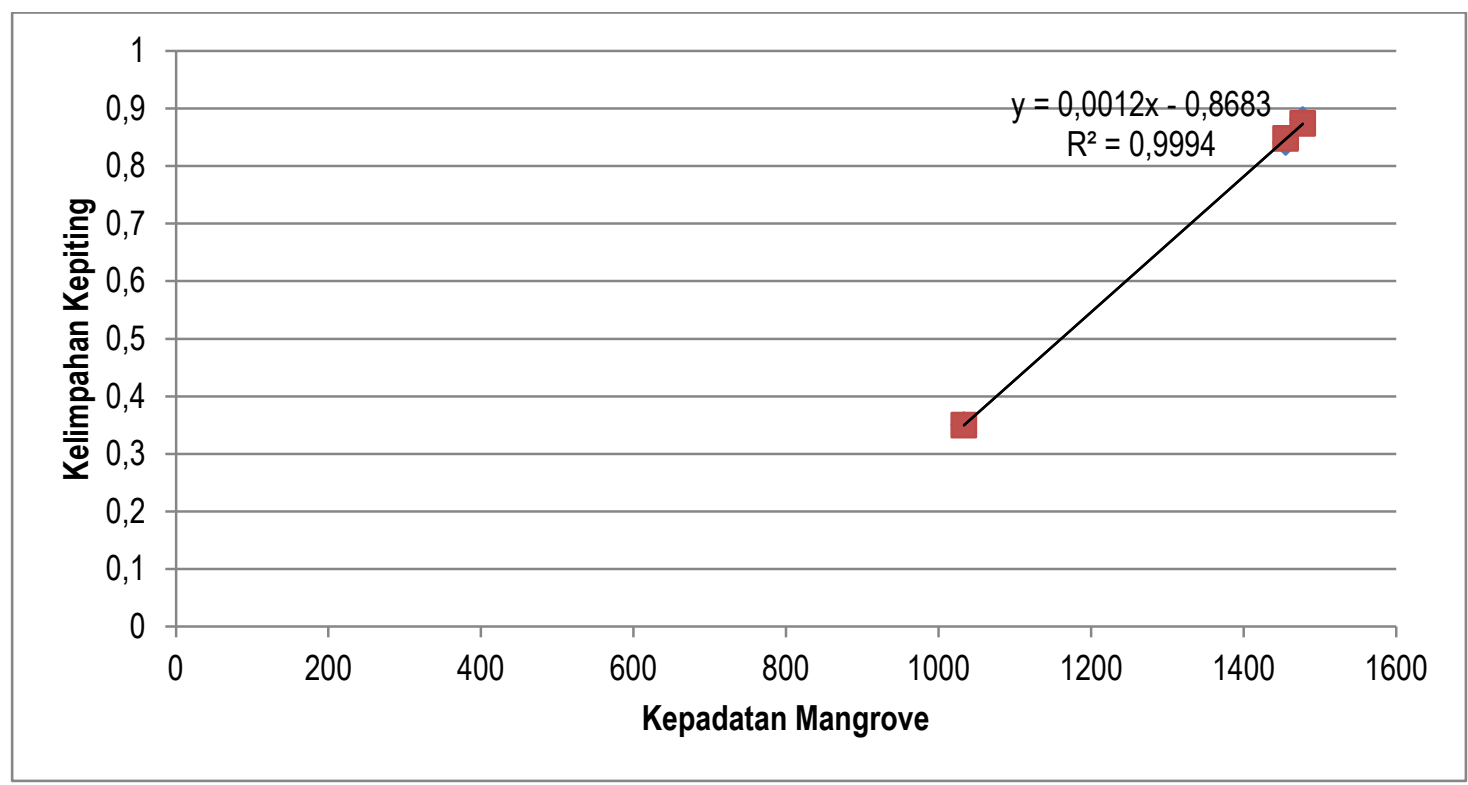

Gambar 2. Korelasi Kepadatan Mangrove (x) dan Kelimpahan Kepiting (y)

Table 7. Validasi Kriteria Bioindikator terhadap Kepiting Familis Sesarmidae

\begin{tabular}{|c|c|c|}
\hline No & Kriteria & Uraian Kreteria \\
\hline \multirow[t]{4}{*}{1} & $\begin{array}{l}\text { Memiliki taksonomi, biologi, dan ekologi yang jelas dan diketahui } \\
\text { dengan baik }\end{array}$ & Terpenuhi \\
\hline & $\begin{array}{l}\text { a) Taksonomi jelas dan dapat ditelusuri: Dimana } 10 \text { spesies kepiting } \\
\text { ditemukan di Teluk Youtefa, } 6 \text { spesies dapat teridentifikasi, } \\
\text { teridentifikasi hingga ke level spesies }\end{array}$ & $\begin{array}{l}\text { famili Sesarmidae yang } \\
\text { dan } 4 \text { spesies belum }\end{array}$ \\
\hline & b) Biologi: Perilaku reproduksi yang diketahui dengan jelas dan dapat di & telusuri \\
\hline & $\begin{array}{l}\text { c) Ekologi: Perilaku berasosiasi dan bersarang diketahui jelas dan } \mathrm{d} \\
\text { Sesarmidae berasosiasi dengan tumbuhan mangrove sebagai tem } \\
\text { makan, dan berlingdung }\end{array}$ & $\begin{array}{l}\text { apat ditelusuri, Kepiting } \\
\text { pat bersarang, mencari }\end{array}$ \\
\hline \multirow[t]{2}{*}{2} & Korelasi terhadap perubahan ekosistem dapat ditetapkan & Terpenuhi \\
\hline & $\begin{array}{l}\text { a) Analisis Keanekaragaman kepiting: tingkat Keanekeragaman spe } \\
\text { dengan kisaran nilai indeks } 1,56-1,79 \text {. Selaras dengan kondis } \\
\text { berdasarkan tingkat kerapatan vegetasi dikatorikan sedang dan baik } \\
\text { b) Analisis Kemerataan: Kemerataan spesies kepiting Sesarmidae dika } \\
\text { dan stabil dengan kisaran kepadatan rata-rata } 0,04-0,09 \text {. Selaras de } \\
\text { mangrove berdasarkan tingkat kerapatan vegetasi dikatorikan sedan }\end{array}$ & $\begin{array}{l}\text { sies sedang melimpah } \\
\text { i ekosistem mangrove } \\
\text { atagorikan sedang tinggi } \\
\text { gan baik }\end{array}$ \\
\hline
\end{tabular}

3 Sensitif terhadap tekanan lingkungan

Terpenuhi

Analisis Kelimpahan: Hasil perhitungan ini menunjukan spesies tidak tersedia melimpah pada ketiga stasiun dengan nilai kepadatan rata-rata 0.92-0.97 individu per unit sampling. Kelimpahan kepiting sangat dipengaruhi dan ditentukan oleh kepadatan mangrove.

$4 \quad$ Spesialisasi Terpenuhi

Analisis Dominansi: Tidak ada spesies yang bersifat dominan dalam populasi kepiting Sesarmidae dengan nilai indeks dominansinya 0,19-0,22. Selaras dengan kondisi ekosistem mangrove berdasarkan tingkat kerapatan vegetasi dikatorikan sedang dan baik 


\begin{tabular}{clc}
\hline No & \multicolumn{1}{c}{ Kriteria } & \multicolumn{1}{c}{ Uraian Kreteria } \\
\hline 5 & $\begin{array}{l}\text { Penghuni tetap dan asli setempat } \\
\text { Famili Sesarmidae merupakan kepiting ekosistem mangrove yang } \\
\text { merupakan penghuni tetap. Kepiting ini menghabiskan seluruh siklus } \\
\text { ekosistem mangrove }\end{array}$ \\
\hline $6 \quad \begin{array}{l}\text { Memiliki kebutuhan habitat yang sama dengan organisme lain dan di dalam } \\
\text { habitatnya lebih heterogen }\end{array}$ \\
$\begin{array}{l}\text { Kepiting Sesarmidae dan vegetasi mangrove bersimbiosis secara mutualisme, Kepiting ini } \\
\text { memiliki kebutuhan habitat yang sama dengan beberapa Bivalvia diantaranya Famili Mytilidae, } \\
\text { Anomiidae, Malaidae, Ostraidae, dan Spondilydae (Abbott, 1991) }\end{array}$ \\
\hline
\end{tabular}

\section{Simpulan}

\begin{abstract}
Status kesehatan ekosistem mangrove berdasarkan tingkat kepadatan vegetasi mangrove dan tingkat keanekaragaman kepiting tergolong sedang dan baik. Kepiting Sesarmidae memenuhi enam kriteria biologi indikator ekosistem Mangrove Teluk Youtefa. Kepiting ini dapat digunakan sebagai biologi indikator dalam penelitian status kesehatan ekosistem mangrove.
\end{abstract}

\section{Daftar Referensi}

Abbott, R. T., 1991. Seashells of Southeast Asia. Graham Brash, Singapore.

Ashton, E. C., Macintosh, D. J. and Hogarth P. J., 2003. A Baseline Sstudy of the Diversity and Community Ecology of Crabs and Mollusca Macrofaunca in Sematan Mangrove Forest. Sarawak, Malaysia. Journal of tropical ecology.

Faber-Langendoen, D., Rocchio, J., Schafale, M., Nordman, C., Pyne, M., Teague, J., Foti, T. and Comer, P., 2006. Ecological Integrity Assessment and Performance Measures for Wetland Mitigation. NatureServe, Arlington, Virginia.

Fachrul M. F., 2007. Metode Sampling Bioekologi. Bumi Aksara. Jakarta.

Geisen, W., Wulffraat, S., Zieren, M. and Scholten, L., 2007.Mangrove Guide for Southeast Asia. FAO Regional Office for Asia and the Pacific Maliwan Mansion

Jorgensen, S.E. Costanza, R. and Fu-Liu Xu. eds. 2005. Handbook of Ecological Indicators for Assessment of Ecosystem Health, CRC Press.

Kalor, J. D., 2012. Mangrove Crabs Diversity as The Bio-Indicator for the Ecology of Mangrove Ecosystem at Gam BaySawinggrai Research Station, Raja Ampat, Papua.Thesis, Goerg August University of Goettingen, Germany- Lincoln University, New Zealand.

\section{Ucapan Terimakasih}

Penulis menyampaikan terimakasih kepada Direktorat Riset dan Pengabdian Masyarakat (DRPM) KEMENRISTEK DIKTI yang telah mendanai penelitian ini. Juga kepada Lembaga Penelitian dan Pengabdian Masyarakat (LPPM) Universitas Cenderawasih yang telah memfasilitasi penulis dalam proses pengajuan proposal, pelaksanaan pengambilan data, dan monitoring dan evaluasi penelitian ini.

Kathiresan, K. and Bingham, B. L., 2001. Biology of Mangrove and Mangrove Ecosystem. Advances in Marine Biology. 40.pp 81-251.

Khouw, A.S. 2009. Metode dan Analisa Kuantitatif dalam bioekologi laut. Jakarta. Pusat Pembelajaran dan Pengembangan Pesisir dan Laut ( P4L). Direktorat Jenderal Kelautan, Pesisir dan Pulau-pulau Kecil (KP3K). DKP. Jakarta

Krebs, C. J., 1985. Ecology: The Experimental Analysis of Distribution and Abudance, Third Edition. Harper \& Row, Publisher, Inc.

Macintosh, D. J. Ashton, E. C. and Havanon, S., 2002. Mangrove Rehabilitation and Intertidal Biodiversity: a Study in the Ranong Mangrove Ecosystem, Thailand. Estuarine, Coastal and Shelf Science, 55. Pp 331-345.

Magurran, A. E., 1988. Ecological Diversity and Its Measurement. Princeton University Press. Princeton, New Jersey, USA.

Nordhaus, I. 2003. Feeding Ecology of the semiterrestrial crab Ucides cordatus ( Decapoda: Brachyura) in a Mangrove Forest in Northern Brazil . Dissertation, Zentrum für Marine Tropenökologie (ZMT), Universität Bremen.

Noor, R. Y., Khazali, M., \& Suryadiputra, I. N. N., 1999. Paduan Pengenalan Mangrove di Indonesia, PHKA/WI-IP, Bogor.

Odum, E. P., 1971. Fundamental of ecology. W.B. Sunders Co. 
Primack B. R., 2006. Essential of Conservation Biology, Fourt Edition. Sinauer Associates, Inc. Publisher. Massachusetts, USA.
Rahayu, D. L. and Setyadi, G., 2009. Mangrove Estuary Crabs of the Mimika. PTFI-LIPPI. PT. Indonesia Printer. 